\title{
Simülasyon Argümanı ve İnsanın Özü: The Congress Filminde Güzellik Algısının Sinematik Evreni
}

\author{
Selen Gökçem Akyıldız (Dr. Öğr. Üyesi) \\ Niğde Ömer Halisdemir Üniversitesi Illetişim Fakültesi \\ gkselen@gmail.com \\ Başvuru Tarihi: 17.03 .2021 \\ Yayına Kabul Tarihi: 10.05.2021 \\ Yayınlanma Tarihi: 30.07.2021 \\ https://doi.org/10.17680/erciyesiletisim. 898670
}

\section{Öz}

Hollywood'un içinde bulunduğu Batı kültürünün temel taşlarından birisi olan güzellik mitinin, 1930'lu yıllarda başlayan yıldız sistemi ile doruğa ulaşması ve takip eden yıllarda bilhassa kadınların fiziksel görünüşlerini belirleyen kuralları çerçevelediği bilinmektedir. Ne var ki teknolojik gelişmeler ıșığında gençliğin ve güzelliğin övülmesi, daha uzun yıllar yaşlanmaktan kaçınılmasının telkin edilmesi, yaşlılığın insanı bir hiçe çevirmesi fikri sosyal medyanın da yardımı ile her geçen gün toplumda kabul gören bir düşünce haline gelmektedir. Ari Folman'ın yönettiği, fütürist bir distopya filmi olan The Congress (Son Şans), Stanislaw Lem'in The Futurological Congress (1971) adlı kitabından esinlenerek gerçek ve anime edilmiş görüntünün bir arada kullanılarak çekildiği bir filmdir. Yönetmen, Hollywood'un güzellik mitinden yola çıkarak, ana akım kültürün bitmeyen metalaşmasına ait göndermeler ile filmi şekillendirmiştir. Bu çalışma, güzellik algısının yanılsama ve gerçeklik teorileri ile harmanlanarak sunulduğu filmde bu algının insanın var oluşunun hiçe sayılması pahasına değerli kılınması üzerinde durmaktadır. Analiz sonucunda ise bir aktrisin kimliğinin dijital imgeyle belirlenmiş yeni film endüstrisinin hizmetinde nasıl yok olduğu ve sanat eserlerinin biricikliklerinin kaybolması gibi, insanların da biricik ve eşsiz olma özelliklerinin geride bırakılarak insan yığınları şeklinde sistemin ilahlaştırdığı kişilere benzemelerinin desteklendiği görüşünün irdelendiği sonucuna ulaşılmıştır.

Anahtar Kelimeler: Sinema, Simülasyon Teorisi, Güzellik Miti, Animasyon, Gerçeklik. 


\title{
The Simulation Argument and the Essence of Human Being: The Cinematic Universe of the Perception of Beauty in The Congress
}

\author{
Selen Gökçem Akyıldız (Asst. Prof. Dr.) \\ Niğde Ömer Halisdemir University Faculty of Communication \\ gkselen@gmail.com
}

Date Received: 17.03.2021

Date Accepted: 10.05 .2021

Date Published: 30.07.2021

https://doi.org/10.17680/erciyesiletisim.898670

\begin{abstract}
Beauty myth is one of the cornerstones of the Western culture in which Hollywood is located and framed rules of physical appearance of women. However, the idea of praising youth and beauty and the idea of old age turning people into nothing, is becoming an accepted idea in society every day with the help of social media. Directed by Ari Folman, The Congress, a futuristic dystopia movie released in 2013, is a film inspired by Stanislaw Lem's book The Futurological Congress (1974). Based on the beauty myth of Hollywood, the director works by transforming his character visiting the World Futurology Congress into the story of a living Hollywood star being forced to choose between reality and an illusionary world. The aim of this study is to examine the presentation of the beauty perception in the cinematic universe by blending illusion and reality theories, making it valuable at the expense of human existence, and creating another illusion by moving the myths of youth and beauty to the parallel universes created by analyzing content.
\end{abstract}

Keywords: Cinema, Simulation Theory, Beauty Myth, Animation, Reality. 


\section{Giriş}

Eski Fransızca "beauté" kelimesinden gelen güzellik kelimesi eski İngilizcede fiziksel çekicilik, iyilik ve nezaket anlamlarına gelmektedir. "Beauté" kelimesi Latince güzel, yakışıklı, çekici anlamına gelen bellus kelimesine dayanmaktadır (Skeat, 2015). Bugün ise duyulara zevk veren, ruhu ve zihni yücelten bir kişi ya da şeydeki niteliklerin toplamı; özellikle güzel kadın ve zarif, süslü veya mükemmel kalitede olan anlamlarına gelmektedir (Merriam-Webster, 2021). Güzellik teriminin birden çok bağlamda kullanıldığı ve birçok alt kategoriye ayrılabileceği açıktır. Tarihsel olarak güzellik, kişiliğin ve tavrın iyiliğini tanımlamak için kullanılan "iç güzellik" ve estetik görünümle ilgili "dış güzellik" olarak ikiye ayrılmıştır. Felsefi ve sanatsal olarak bu iki güzellik alt kümesinin birbiriyle ilişkili olduğu tartışılmıştır. Yüzyıllar boyu dış güzelliğin iç güzelliği temsil ettiği inancı yüceltilmiş, Francis Bacon, "erdem, iç güzellikten başka bir şey değildir; güzellik erdemden bașka bir șey değildir" (Bacon, 1884) cümlesini sarf etmiștir. Ancak, nesiller boyunca neyin güzel olduğuna dair algllar ve düşünceler değișip gelişmiş ve çeşitlenmiştir.

Görsel sanatlarda özellikle kadın bedeni üzerinden şekillenmeye başlayan güzellik algısı, zamanla güzellik mitine dönüşmüş, kitle iletişim araçlarının yaygınlaşması ile reklamlara, oradan Hollywood'un içine sızarak güzel yıldız oyuncu imgesinin yaratılmasına kadar gelmiştir. İlerleyen yıllarda teknolojik gelişmeler ile birlikte önce makyaj daha sonra da estetik operasyonların yaygınlaşması günümüzde ise çeşitli programlar ile kusurların giderilerek herkesin mükemmel ölçülere sahip olduğu güzellik algısının ortaya çıkması, güzellik simülasyonunun üzerinde durulması gereken bir tartışma alanı yarattığının altını çizmektedir.

Jean Baudrillard'ın (2014) bilgi teknolojisi, medya ve sibernetiğin endüstriyel üretim çağından, modellerin, işaretlerin ve kodların gerçeğe erişmesine aracılık ettiği ve gerçekliği tanımlamayan bir simülasyon çağına girildiğini iddia etmesi ve simülasyon ile gerçeklik arasında mantıklı bir ayrım yapmanın artık neredeyse mümkün olmadığını belirtmesi, Ari Folman'ın The Congress (2013) filminde güzellik simülasyonu ile birleşerek tartışmayı başka bir boyuta taşımaktadır. Stanislaw Lem'in The The Futurological Congress (Lem, 1971) isimli bilimkurgu hikayesinden yola çıkarak simülasyon kavramını bir Hollywood yıldızının bölünen hayatı üzerinden veren yönetmen, hem gerçek ve fantazmatik hayatın birbirine geçmiş bulanıklığını hem de güzellik algısının insanın varlığının önüne geçerek kişilerde yarattığı bölünmeyi halüsinasyonlarla yaratılan animasyonun da işin içine girdiği başka bir evrene taşımaktadır.

Çalışmada üzerinde durulmak istenen nokta, gerçek ve simülasyon kavramlarının iki farklı evrendeki sunumunun reel bir Hollywood yıldızının bölünen hayatı, yalnızca geçici güzelliğine verilen meta değeri ve kişilik bölünmesi üzerinden veren The Congress (2013) filminde, simülasyon kavramının kitle iletişim araçları alanından çıkarak içinde yaşamayı tercih ettiğimiz simülasyon evrenine dönüşmesi durumudur. Yirmi birinci yüzyılda internetin gelişmesi ve akıllı telefon kullanımının yaygınlaşması ile sosyal medya devri başlamıştır (Williams, 2012). Sosyal medya kullanımının ve yarattığı dijital evrenin kendisinin bir simülarka dönüşmesi, oluşturulan profillerin kişileri temsil eden yeni kimliklere evrilmesi, kişilerin reel ve simülasyon olmak üzere iki hayat yaşamasına neden olmaktadır.

Görüntü paylaşımı üzerinden ilerleyen sosyal mecralarda ise güzellik en temel konulardan birisi haline dönüşmüştür. Girl Scouts of America tarafından 2010 yllında yapılan bir araştırmaya göre ankete katılan 1000'den fazla genç kızın \%88'i medyanın 
zayıf olmaları için çok fazla baskı yaptığını, \%65'i moda endüstrisinde temsil edilen beden imajının çok zayıf olduğunu ve \%60’ı vücutlarını dergilerde gördükleri ile karşılaştırdıklarını söylemektedir (Davis, 2016). Güzellik algısının en belirgin şekilde metalaştırıldığı sektörlerden birisi olan sinema ve yıldız sistemini simülasyon evreni ile birleștiren yönetmen Folman'ın filmi, birbirleri ile temas etmiyor gibi görünen iki konuyu yaşayan bir yıldız üzerinden resmetmesi ve izleyiciye farklı bir bakış açısı sunması yönünden önemlidir.

Çalışmanın ilk bölümü güzellik algısı, güzellik miti ve simülasyon kavramlarına odaklanırken, ikinci bölümde The Congress (2013) filmi yönetmenin konuyu nasıl kavradığı, hangi açıdan baktığı ve nasıl yorumladığı ile ilintili olarak içerik analizi temel alınarak ilk bölümde bahsi geçen güzellik ve simülasyon kavramları üzerinden tartışılarak analiz edilmektedir.

İçerik analizi, örneğin üretim uygulamaları, temsil veya resmi ortak paydalar hakkında bilgi üretmek için bir dizi film metninin ampirik çalışmasını ve teorik analizini içerir. Mevcut medya içeriğinin analizi, film yapımcılarına, izleyicilerin filmlerindeki öykülere ve karakterlere yönelik eğilimleri hakkında daha net bir kavrayış sunarak, sosyal veya anlatı klişelerini sorgulamalarına veya stratejik olarak kullanmalarına olanak tanımaktadır. Mevcut medyanın içerik analizi, seyircilerin filmlerindeki öykülere ve karakterlere yönelik eğilimlerini daha net bir şekilde kavrayarak, toplumsal veya anlatı yapısındaki klişelerini sorgulamalarını, azaltmalarını veya stratejik olarak kullanmalarını sağlar (Brylla, 2018). Medya akademisyeni Beth Haller (2010) içerik analizinin izleyicilerin kişisel deneyimler ve kitle iletişim araçları bilgisi yoluyla gerçekliği anladıkları batı toplumunun kitlesel arabuluculuğunu kabul etmekle kalmadığını aynı zamanda o anın sosyal gerçekliğini ve kültürünü de güvenilir bir şekilde ortaya koyduğunun altını çizer. Bu anlamda içerik analizi ile üretilen veriler, film yapımını ve seyirci uygulamalarını yalnızca gerçek bir film metni açısından değil, aynı zamanda bağlamı açısından da açıklayabilir, metinlerarasılıkla ve en önemlisi sosyo-kültürel eğilimle bağlantılı uygulamaları ortaya çıkarabilir. İzleyici perspektifinden bakıldığında içerik analizi, izleyicilerde yankı uyandıran ancak potansiyel olarak basmakalıp veya klişe temsillere yol açan film yapma uygulamalarına da ışık tutar. Bu çerçevede güzellik algısı ve simülasyon kavramları odağında analiz edilen The Congress filminin izleyiciye kazandırdığı yeni bakış açısının hangi kodlar ve temsiller ile yapıldığının incelenmesi içerik analizi yöntemi ile yapılmaktadır. The Congress filmini simülasyon kavramı ve güzellik miti ile birleștirerek analiz etmiş bir incelemeye rastlanmaması ve güncel bir konu olan güzellik algısının insanlar üzerindeki olumsuz etkisini de içeren bir film olması nedeniyle bu film seçilmiştir. Çalışmanın, üzerinde durulan iki kavrama farklı bakış açısı sunabileceği ve ortaklaştığı noktalardan yola çıkılarak farklı incelemelere yardımcı olabileceği düşünülmektedir.

\section{Güzellik Miti}

Fiziksel görünüm, başkaları tarafından fark edilen ilk bireysel özelliklerden biridir ve sosyal etkileşimler üzerinde önemli bir etkiye sahiptir. Genel olarak görünüm ve özelde beden imajı, çağdaş Batı toplumlarında çok önemli yapılar haline gelmiştir (Tiggemann, 2011). Beden imgesi sadece bilișsel bir yapı değil, aynı zamanda başkalarıyla olan tutum ve etkileşimlerin de bir yansımasıdır. Fiziksel çekiciliği olumlu kişisel niteliklerle ilişkilendirme eğilimi, yalnızca batı kültüründe değil, aynı zamanda küresel olarak kültürel bir klişe haline gelmiştir. En genel tanımıyla güzellik idealleri, insan yüzünün ve vücudunun çeşitli özelliklerini içeren ve dolayısıyla bir kültür içindeki 
fiziksel çekicilik standartlarını tanımlayan, kültürel olarak belirlenmiş ve onaylanmış "görünüşleri" temsil eder.

Umberto Eco güzellik üzerine yazdığı kitabı On Beauty (Eco, 2004) de güzel, harikulade, mükemmel, muhteşem gibi ifadelerin sevdiğimiz bir şeyi belirtmek için kullandığımız sıfatlar olduğunu söyler. Bu minvalde, güzel olanın iyi de olduğu anlaşılmaktadır ve tarihsel dönemlere bakıldığında güzel olan ile iyi olan arasında bir bağ da vardır. Ancak günlük deneyimlerimize dayanarak bir çıkarım yaparsak yalnızca sevdiğimiz değil sahip olmak istediğimiz şeyleri de iyi olarak tanımlama eğiliminde olduğumuz ortaya çlkar. Güzel olan arzumuzu harekete geçirendir. Diğer taraftan iyi ile özdeşleştirilmiş güzel bizden fedakârlık yapmamızı, acı çekmemizi istiyorsa o zaman o iyiyi başkasının iyisi olarak görür ve onun için bir arzu duymayı.

Felsefe yapılmaya başladığından bu yana güzelliğin, özellikle insan vücudunun güzelliği üzerine tartışmalar hiç durmadan devam etmiştir. Platon'un görüşüne göre beden, ruhu hapseden karanlık bir mağara olduğu için, duyuların görüşü, diyalektik sanatlar, diğer bir deyişle felsefe hakkında bilgi sahibi olmayı gerektiren entelektüel bakışla aşılmalıdır. $\mathrm{Bu}$ nedenle herkes gerçek güzelliği kavrayamaz. Sanat ise güzelliğin sahte bir kopyası olduğundan onu orantıya ve evrenin matematiksel bir kavramına dayanan geometrik formların güzelliği ile ikame etmek gerekir. Antik Yunan'da güzellik, özellikle harmoni ve simetri ile ilişkilendirilmiştir. Bununla birlikte Yunan heykelleri somut bir bedeni idealize etmek için yapılmamış, aksine beden ve ruhu uyumlu hale getiren psikofiziksel bir güzelliğin ifadesi için araç olan canlı bedenlerin sentezi yoluyla ideal bir güzelliği aramıştır (Eco, 2004, s. 44)

Güzellikle ilgilenen orta çağ filozofları, ilahiyatçıları ve mistiklerin, kadınların güzelliği ile uğraşmak için çok az nedenleri vardır çünkü hepsinin kiliseye mensup erkeklerdir ve orta çă̆ ahlakı bedenin zevklerine güvenmemelerini emreder. Ancak bu kiliseye mensup erkekler Şarkıların şarkısını alegorik olarak yorumlamak zorunda kaldıklarında bu dogmatik metinlerin tamamen üzeri örtülmemiş bir duyarlılığı ortaya çıkaran kadınsı güzelliğe de atıfta bulunduğunu görmüşlerdir. Yorumlanan pasajın bir kısmında kadınların gögüslerinin nasıl, hangi ölçü ve şekilde olması ve hangi biçimde örtülmesi gerektiğinden bahsedilmektedir (Eco, 2004, s. 154) 1300’lü yıllarda Giovanni Boccasccio Beautiful Woman (Güzel Kadın) adlı şiirinde bir kadının yüz güzelliğini, kirpiklerini, saçlarını, neşe dolu alnını tasvir ederek nasıl da bir meleğe benzediğini anlatır.

Kadınlara atfedilen güzellik normları yüzyıllar boyunca farklılaşarak, o dönemin standart güzellik algısının belirlenmesine hizmet etmiştir. Güzellik algısının nasıl değişken olduğu en açık şekilde dönemin popüler sanat eserlerinde görülmektedir. Örneğin, Botticelli'nin Venüs'ün Doğuşu adlı eserinde güzellik tanrıçası, yuvarlak yüzlü ve armut biçimli gövdesiyle endomorfik bir şekle sahiptir (Swami, 2007). On dokuzuncu yüzyıla gelindiğinde kadınların dolgun bedenlerine de sınırlama getirilmeye başlandığı ve bu dönemde batı kültüründe kadın güzelliğinin kitlesel standartlaşmasının, gerçekçi ve doğal olmayan vücut ideallerinin teşvik edilmesinin ilk aşamalarının görüldüğü söylenebilmektedir.

Kısıtlayıcı bir kıyafet seçimi olan korse on altıncı yüzyılda ortaya çıkmış ve yalnızca aristokrat kadınlar için giyilmesi zorunlu bir kıyafet olmasına rağmen on dokuzuncu yüzyılda neredeyse tüm sınıflardan kadınlar için bir moda haline gelmiştir. Korsenin kadınların belini olduğundan çok ince göstererek öne çıkarmak istedikleri diğer vücut hatlarını da desteklemesi, kadınların şehvetli görünmelerini sağlayan bir kıyafet olarak 
kullanımını arttırmıştır (Kunzle, 2004). Bu idealize edilmiş kum saati beden figürüne ulaşmak özel giysiler olmaksızın mümkün değildir ve bu nedenle kadınların vücutlarını doğal olmayan ölçülere uydurmak için çalıșmaları gerekmiştir.

On dokuzuncu yüzyılın ortalarında ideal kadın güzelliğine yenileri eklenmeye başlanmıştır. Banner'a göre (1983) bu yeni ideallerden birisi Steel Engraving Lady adı verilen sürekli kocasının gücüne, zekâsına ve genel üstünlügüne bağlı kalan kırılgan, kibar ve zarif bir kadın idealidir. Bu tip kadınların günleri evi temizleyip, yemek yapıp misafir ağırlamak ile geçmektedir. Fiziksel görünüş bakımından ise bu kadınlar kızarmış yanakları, korseli belleri, oval veya kalp şeklindeki yüzleri, küçük dudakları ve minik hassas elleri ve ayaklarıyla soluk tenlilerdir (White, 2009). 1861'de İç Savaş'ın başlamasından önce, tüm ulusu kasıp kavuran bu ideal kadın figürü, karakteristik olarak küçük, soluk, zayıf ve neredeyse hasta görünüme sahiptir. Tüberküloz nedeniyle zayıflayan hastaların kiloları kadınlar tarafından ideal zayıflık olarak görülmeye başlanmış ve hastalığın kendisi acımasız, korkunç ve ölümcül olmasına rağmen opera, roman ve zamanın diğer toplumsal ifade biçimleri ile romantize edilmiştir (Moe, 1999).

Günümüzde kişisel fiziksel imaj, sosyal çevrede ayrı bir yer edinmenin bir yoludur. Bu statüyü elde etmek için vücut görünümüne yapılan yatırımlar (kozmetik ürünler ve çeşitli uygulamalar, piercing ve dövmeler, estetik ameliyatlar, spor malzemeleri ve ekipmanları vb.) kadınlar ve erkekler için de önemli ölçüde artmıştır. Naomi Wolf The Beauty Myth (1991) adlı kitabında güzellik algısının nasıl politik, ideolojik ve insanlar üzerinde güç olarak kullanabilen bir terime dönüştüğünü anlatmıştır. Wolf'a (1991, s. 12) göre güzellik bir para sistemidir. Her ekonomi gibi, siyaset tarafından belirlenir ve Batı'da modern çağda erkek egemenliğini sağlam tutan son en iyi inanç sistemidir. Kültürel olarak dayatılan fiziksel bir standarda göre dikey bir hiyerarşide kadınlara değer atarken, kadınların doğal olmayan bir şekilde erkeklerin kendileri için tahsis ettikleri kaynaklar için rekabet etmeleri gereken güç ilişkilerinin bir ifadesi haline gelmiștir.

Gençlik ve yaşlılık iki zıt kutbu, güzel olan ve güzel olmayanı temsil eder. Gençlik cehaleti temsil ettiği için kadınlarda güzel olarak ele alınır. Kadınlarda yaşlanmak güzel değildir çünkü kadın yaşlandıkça güçlenir ve zamanla genç ve yaşlı kadın arasındaki bağın kopması gerekir. Yaşlı kadınlar gençlerden, genç kadınlar da yaşlılardan korkar ve bu güzellik efsanesi kadının tüm hayatı boyunca devam eder (Wolf, 1991, s. 13). Böylelikle politik, ideolojik ve endüstriyel bir içeriğe sahip güzellik miti bir hayalet gibi insanların üzerinde salınır.

\subsection{Küresel Güzellik Sektörünün Yükselişi}

Kadınlar yüzyıllardır güzelliklerini ön plana çıkarmak için boya ve çeşitli karışımlar kullanırken, çokuluslu şirketler ve onların reklam ajansları kadınların güzelliğe ve çekiciliğe olan ilgisini kâr için akıllıca kullanmayı ancak yirminci yüzyılda öğrenmişlerdir. Modern güzellik endüstrisinin ortaya çıkışı, seri üretim ve kitlesel pazarlamanın potansiyelinden ve bilimsel araştırmanın endüstriyel ürünlere uygulanmasından kaynaklanan yeni olanaklar tarafından yönlendirilmiştir. Güzellik endüstrisi, kendisini alışılmadık bir ilgi alanı haline getiren bir dizi ayırt edici özelliğe sahiptir. Ürünlerinin çoğunun başlangıçta kadınlara pazarlandığını, büyük reklam bütçeleriyle hareket ettiğini, sağlık / bilim ve estetik / güzellik alanlarını kapsadığını, talebin köklü kültürel ve toplumsal normlar tarafından șekillendirildiğini ve ürünlerinin, bireylerin kendilerini ve başkalarını nasıl algıladıklarını etkilediği algı farklılığı yaratan bir sektör olarak yola çıkmıştır (Jones, 2005, s. 2). Bir güzellik primi oluşturan bu endüstrinin ürünleri 
ile geliștirilebilecek fiziksel çekicilik, cinsel partnerleri etkileme yeteneği, ömür boyu sürecek kariyer firsatları ve kazançlar, bireysel yaşam tarzları üzerinde büyük bir etki yaratmaktadır.

On dokuzuncu yüzyılın ikinci yarısında modern bir güzellik endüstrisinin ortaya çıktı̆̆ı konusunda genel bir fikir birliği vardır. Artan isteğe bağlı gelirler, kentleşme ve değişen değerler, özellikle Amerika Birleşik Devletleri’nde hızlı büyümeyi teşvik etmiştir. Daha sonra hijyen uygulamaları ve güzellik idealleri geniş çapta yayılmıştır. Modern güzellik endüstrisinin ortaya çıkışı, seri üretim ve kitlesel pazarlamanın potansiyelinden ve bilimsel araștırmanın endüstriyel ürünlere uygulanmasından kaynaklanan yeni olanaklar tarafından yönlendirilmiștir. Yükselen gelirler, artan sayıların ihtiyari harcamalara katılmasını sağlamıştır. Hızlı kentleşme, hijyen ve hastalıkların önlenmesi konusundaki endişeleri artırmıştır (Miskell, 2004, s. 32).

Modern bir güzellik endüstrisinin ortaya çıkışı, on dokuzuncu yüzyılın ikinci yarısında dünya ekonomisinin hızlı küreselleşmesi ile aynı zamana denk gelmiştir. Jones'a (2005) göre bu endüstrinin büyümesinde değerlerin önemi göz önüne alındığında, yarı ideolojik bir rol üstlenmesi şaşırtıcı değildir. Bazı hijyenik uygulamalarda hızlı bir küreselleşme yaşanmıştır. Sabun ihracatı, sömürgeleștirilmiş insanları "uygarlaștırma" misyonuna önemli bir katkı olarak görülmeye başlanmış, Güney Afrika sömürgeciliğinde, yerli Afrikalıların hijyenik alışkanlıklardan yoksun olduğu iddiası, sömürgeci ırkçı söylemin önemli bir bileşenini oluşturmuştur (McClintock, 1995).

Güzellik endüstrisinin büyümesinin ikinci aşaması, Hollywood'un kadınların öz algıları üzerinde ilk kez büyük bir etkiye sahip olmaya başladı̆̆ı 1920'lerde başlamıştır. Hollywood yıldızları döneminden önce pancake makyajı olarak bilinen yüzün parlamasını ve terlemesini önlemek ve varsa kusurları kapamak için kullanılan güzellik ürünleri ve yöntemleri kullanılmıştır. 1900'lerin başında Polonyalı Max Faktorowicz gibi isimler makyaj sektörüne adım atmış, film yıldızlarının olduğu Hollywood'a giderek burada yeni makyaj ürünlerini pazarlamışlardır. Bu yeni makyaj ürünleri kusurları gizleyebilir, bir kadının doğal güzelliğini arttırabilir niteliktedirler. Böylelikle, 1920’lerin başında makyaj güzelliğin göstergesi olarak reklamda temizliğe göre öncelik kazanmaya başlamıştır (Frith, 2014, s. 20).

Margaret Illington Banes 1912'de The Mad Search for Beauty ismiyle yazdığı makalede bir kural olarak aktrislerin, kendilerini güzelleștirmek konusunda sıradan bir kadından daha fazla şey bilmediklerini ve doğal olarak daha güzel de olmadıklarını belirtir. Aktrislerin kendilerini "güzellik uzmanları" olarak sunmalarını gerektiren tiyatro mesleğindeki son eğilimlerden rahatsız olan Banes (1912, s. 953), sahne içi ve dışı performanslarının yapılandırılmış doğasını ortaya çıkarmaya çalışmıştır. Banes'e göre sahnedeki yıldızların izleyici büyülemesinin sebebi sahne ışığı altında giyebilecekleri sayısız fırsatın olmasıdır.

1910'da kadınlar sahne modasını yeniden yaratmak, aktrislerin saç ve kıyafet stillerini ve diğer aksesuarları kopyalamak için çeşitli teknikler kullanmışlardır. Kozmetik ürünler, korseler ve diğer moda ürünlerinin reklam verenleri için ise oyuncularla referans reklamcılık yoluyla bir ilişki kurulmasının önemi hızlı bir şekilde anlaşılmıştır. Daha sonra taklitçi heves olarak adlandırılacak, kadınların aktrislerin kullandığı herhangi bir ürüne derhal sahip olmak istemeleri durumu kullanılacak bir pazarlama stratejisine dönüşmüștür (Schweitzer, 2005, s. 255). 
Öte yandan, kadınları yıldızları taklit etmekten caydırmak yerine, aktrisin diğer kadınlardan "doğal olarak daha güzel" olmadığının ortaya çıkması, "güzelliğin demokratikleşmesini" desteklemiștir. Bu sayede her kadının kendini olabildiğince güzelleştirme hakkına, kapasitesine ve yükümlülügüne sahip olduğu fikrinin altı çizilmiştir. Kadın izleyicilerin sahnedeki yıldızları hevesle takip etmeleri son dakika haberleri veya dedikoduları kültürel sermaye olarak birbirleri ile paylaşmalarına da sebep olmuştur. Pek çok kadın daha önce hiç tanışmadıkları ama çekici bir modern kadın imajını temsil eden oyunculara kendilerini yakın hissetmişlerdir (Schweitzer, 2005, s. 267).

1910'da sinema, Amerika Birleşik Devletleri'ndeki en popüler eğlence biçimlerinden biri haline gelmiş olmasına rağmen, film oyuncularının çeşitli ürünleri desteklemeye başladığı 1916 yılına kadar referans reklamlarından yoksun kalmışlardır. Richard deCordova'ya (1990, s. 10) göre sinema oyuncularl 1909 gibi erken bir tarihte halk tarafından ismen tanınırken, bu resim kişilikler henüz tam anlamıyla "yıldızlar" değillerdir. Ancak 1914'te, dergi ve gazeteler film yıldızlarının özel hayatları hakkında bilgi vermeye başladığında, bu sanatçılar kendi başlarına yıldız olmaya başlamışlardır. Reklamlarda ve çeşitli billboardlarda görünmeye başlayan ünlüler Alperstein'in deyimiyle gerçek sosyal ilişkilerden oluşan karmaşık bir sisteme benzetilebilecek metinler arası bir ağ yaratmaya (Alperstein, 1991, s. 49) başlamıştır.

İnce kadın bedenleri dergilerde boy gösterdikçe, 1920’lerin ortalarında genç kadınlar arasında bir yeme bozukluğu salgını ortaya çıkmıştır. Harrison'a göre (Harrison, 2006) yeme bozukluğu alışkanlığının en yaygın görüldüğü dönem ideal kadının Amerikan tarihindeki en ince olduğu iki dönem olan 1920'ler ve 1980'lerdir. Silversten'ın yaptığı bir çalışmaya göre (Silverstein, 1986, s. 524), Vogue ve Ladies Home Journal dergilerinde yer alan kadınlar arasında göğüs-bel oranları 1901-1925 yılları arasında yaklaşık \%60 oranında azalmıştır. 1940'ların sonlarına gelindiğinde azalan göğüs-bel oranının yaklaşık üçte bir oranında artarak geri yükseldiği görülmektedir. 1950’lerde Marilyn Monroe gibi dolgun vücut tipleri ve aktrisler popülerlik kazanmışken Playboy dergisinin 1953'te ilk sayısının yayınlanması ile artan beden ölçüleri yeniden düşmüştür. 1960’larda ikinci dalga kadın hareketi ile kadın bedeninin özgürleşmesi adına büyük adımlar atılmasına karşın kadınlar artık kendilerini korselere sıkıştırmasa da ideal vücut ölçülerine sahip olmak adına yapılan toplumsal baskılar devam etmiştir. Bahsedilen ideal ise çok genç ve zayıf bir vücut tipidir. Bu tür bulgular, kitle iletişim araçlarının kadınlar arasında moda olan ince bedensel çekicilik standardını teşvik etmede bir rol oynadığı hipotezine ampirik destek olușturacak niteliktedir.

1980'lere gelindiğinde zayıf kadın görüntüleri ana akım olmaya devam etse de daha güçlü, atletik ve sağlıklı vücut tiplerine daha fazla vurgu yapılmıştır. 2018 yılında yapılan Fashion and Physique sempozyumunda küratör olan McClendon (2018) hala zayıf ancak zinde, fit ve güçlü bir vücuda ilgi gösterilmeye başlandığını ancak 1990'larda zayıf beden vurgusunun tekrar geri döndüğünü belirtmektedir. Yüz güzelliğinden tüm bedenin genç, güzel ve zayıf görünmesine uzanan bu tarihi süreçte 2000'li yıllara gelindiğinde bir başka tehlike olan obezite ile karşı karşıya kalınmıştır. Bir taraftan çok zayıf modellerin imajları dergilerde, televizyonda ve çeşitli mecralarda görülmeye devam ederken diğer taraftan halk sağlığı ile ilintili olarak obez insanların görüntüleri paylaşılmıştır. Moda görüntülerinde aşırı zayıflık alkışlanırken büyük bedenler sağlıksız olarak kötülenmiş ve medyada bedenlerin sunulma biçimlerinde keskin ayrımlar görülmeye başlanmıştır. 
2000’li yıllara gelindiğinde beden algısı ile ilintili olarak küçük yaşlardan itibaren özgüvenin kaybedildiği gözlemlenmiştir. 2015 yllında Children, Teens, Media and Body Image (2015) isimli çalışmaya göre, ABD'de 5 ila 6 yaş arasındaki çocukların yaklaşık üçte biri, seçenek sunulduğunda mevcut bedenlerinden daha ince olan ideal bir vücut bedenini tercih etmekte ve 7 yaşına gelindiğinde her dört çocuktan biri diyet yapmaya başlamaktadır. Yine aynı rapora göre 1999 ve 2006 yılları arasında ABD’de yeme bozuklukları nedeniyle hastaneye yatışların 12 yaşın altındaki çocuklar arasında \%119 arttığını ortaya koymuştur. Yirmi birinci yüzyılda akıllı telefonların artışı ile birlikte sosyal medya kullanımının yaygınlaşması ise insanları iki tarafı keskin bir durumla karşı karşıya bırakmıştır. Bir taraftan özellikle gençlerin beden algıları üzerinde negatif etkiler uyandıracak görüntüler hızla yayılırken diğer taraftan gerçek kadınların pozitif beden algısı sloganları ile paylaştıkları gerçek imgeler görülmeye başlanmıştır. Kozmetik sektörünün yarattığı daha iyi, daha güzel, daha genç algısı medyanın çeşitlenmesi ve akıllı telefonlar yardımı ile her an ulaşılabilir bir sahte gerçeklik, bir simülasyon haline dönüşmüştür.

\subsection{Modern Kimlik Algısı ve Simülasyon Kavramı}

Modern tüketiciler için kullanılan hayali hazcılık kavramı (imaginative hedonism) Campbell'a göre (1948, s. 22) modern nesillere özgüdür. İnsanlar tüketmeyi arzularken ve hayal kurarken, asla tam olarak tanınmayan nihai bir tatmin hedefiyle, mallara olan sürekli özlemlerine kadar uzanan sürekli bir hayal kurma durumunda olurlar. Tüketicilik her şeyi, tüm kimlikleri kapsayan hatta kendimizin bile tüketim için potansiyel birer madde olduğunu betimleyen bir güç olarak ele alınabilir. Bu varsayım dâhilinde Annette J. Saddik (2007, s. 140) kapitalizm altında kimliğin metalaştırılmış bir performans olarak işlev gördüğünü, herhangi bir 'gerçek' veya orijinallik barındırmadığını, daha ziyade iktidar mücadelesinde rollerin ve kostümlerin giyip çıkarılması ile tanımlanacak değișken bir doğası olan bir terim olarak tanımlanabileceğini ileri sürer. Sonuç olarak kimlikler sabit veya durağan varlıklar değillerdir ancak performans ilkesine tabidirler. Diğer bir deyişle, tüketici kültürünün kurallarına, normlarına ve uygulamalarına sürekli maruz kalmanın bir sonucu olarak, kültürel araçların dayattığı düzene uyan, ancak aynı zamanda bunların içinde direniş alanları açan sürekli değişen roller aracılığıyla kendilerini ifade eden, kültürel yapıya meydan okuyan yapılar olarak ortaya çıkarlar (Hüttner, 2010, s. 27).

Kimlik, son yıllarda pek çok farklı bağlam ve amaçla kullanılan belirsiz bir terimdir. Temel kimlik paradoksu Latince kelimenin kendisinden kaynaklanır. Latince kökündeki "idem" terimi, "aynı" anlamına gelir, yine de hem benzerliği hem de farklılığı ifade eder. Kimliğimiz bir anlamda benzersizdir, bizi diğer insanlardan ayıran şey budur. Öte yandan kimlik, ulusal kimlik, cinsiyet kimliği veya kültürel kimlik gibi daha geniş kolektif veya sosyal grupla bir ilişki anlamına da gelmektedir. Sevgi ve önemsenmeye duyulan ihtiyaç insan yaşamının en temel gereksinimlerindendir (Routray, 2019, s. 133). Ancak insanlar "gerçek" dünyada sayısız kaos ve gösteri içinde sevgiyi ve önemsenmeyi kolayca elde edemeyeceklerini düşündükleri için ihtiyaçlarını karşılamak adına sanal gerçeklikte yeni bir dünya kurmanın peşine düşmüşlerdir.

Modern bir toplumda yaşam, konuma, aileye veya cinsiyete dayalı sınırlı seçenekleri olan önceden belirlenmiş bir yol değildir, olasılıklarla doludur. Ancak bireye en iyi seçeneğin ne olduğu konusunda çok az rehberlik verilir. Ailenin, dinin ve geleneksel otoritenin rolü azalmıştır ve modern kurumlar ve sosyal yaşamdaki sürekli değișim dürtüsü, her şeyi belirsiz ve esnek hale getirmiştir. Kendini bulma süreci, sürekli bir dönüşüm süreci 
olan tüm bireylere dayatılır. Kendini tanımlama, modernitede her bireyin iç gözlemsel bir projesi haline gelir. Oysa modern öncesi dönemlerde kimlik, modernitede olanın aksine büyük ölçüde kişiye verilmiştir. Artan seçim olanaklarının avantajları vardır. Örneğin kendini geliştirmenin yeni boyutlarını mümkün kılar; ama aynı zamanda kusurları da vardır (Hermannsdottir, 2011, s. 3). İnsanlar, mevcut seçenekler arasında seçim yapmakta güçlük çektikleri ve doğru seçimleri yapmadıklarından korktukları için kaygı yaşarlar.

Ancak seçimlerin artması, insanların yaşamları veya kimliklerinin şekillendirilmesi üzerinde tam kontrole sahip oldukları anlamına gelmemektedir. Modernitenin, bireylerin yaşamlarına ve kimliklerine tecrübe ve sosyal yaşamın kurumsal baskısı yoluyla ulaşan kontrole yönelik bir eğilimi vardır. Dahası, bireylerin modern toplumdaki yaşamları, üzerinde kontrol sahibi olmadıkları kurumlara, yapılara ve koşullara büyük ölçüde bağımlı hale gelir ve bu, bireylerin özerk olmalarını giderek imkânsızlaşır. Meta kapitalizmi aynı zamanda kendini tanımlama süreci üzerinde güçlü bir kontrole sahiptir çünkü bir benliğin gelişimini belirli mallara sahip olmakla ikame eder ve sürekli olarak karşılayabileceği yeni ihtiyaçlar yaratır.

$\mathrm{Bu}$ yaratılan yeni ihtiyaçlar Baudrillard'ın deyimiyle metalaştırma, makineleşme, teknoloji ve pazar ilişkilerinin patlama sürecinin bir parçası olarak değerlendirilmektedir (Baudrillard, 1967, s. 227). Post modern toplum ise yüksek ve düşük kültürün, görünüm ve gerçeklik arasındaki tüm sınırların, bölgelerin ve ayrımların, geleneksel felsefe ve sosyal teori tarafından hemen hemen diğer her ikili karşıtlığın iç içe geçtiği yerdir. Yayın araçlarının özellikle televizyonun yükselişi, işaretlerin ve simülakranın toplumsal ve günlük yaşamın her alanında hızla yayılmasıyla birlikte, Baudrillard için postmodernitenin önemli bir bileşenidir. 1970'lerin sonlarında Baudrillard, medyayı, günlük yaşamda ve toplumsalın yok edilmesinde anahtar rol oynayan özerk (hiper) bir gerçeklik alanı oluşturan, görüntüleri, işaretleri ve kodları yeniden üreten anahtar simülasyon makineleri olarak yorumlar. Baudrillard için "Simülasyon", kodların, modellerin ve işaretlerin simülasyonun hüküm sürdügü yeni bir sosyal düzenin düzenleyici biçimleri olduğu bir durumu ifade eder. Simülasyon toplumunda kimlikler imgelerin sahiplenilmesiyle inşa edilir ve kodlar ve modeller bireylerin kendilerini nasıl algıladıklarını ve diğer insanlarla nasıl ilişki kurduklarını belirler (Baudrillard, 2014). Ekonomi, siyaset, sosyal yaşam ve kültürün tamamı simülasyon modu tarafından yönetilir; burada kodlar ve modeller, malların nasıl tüketildiğini ve kullanıldığını, siyasetin nasıl ortaya çıktığını, kültürün üretilip tüketildiğini ve günlük yaşamın nasıl yaşandığını belirler.

Buna ek olarak Baudrillard'ın post modern evreni, eğlence, bilgi ve iletişim teknolojilerinin, sosyal etkileşimi yapılandıran kodlar ve modellerin yanı sıra sıradan gündelik hayatın sahnelerinden daha yoğun ve kapsayıcı deneyimler sunduğu bir hiper gerçekliktir. Hiper gerçeklik dünyası gerçekten daha gerçektir, bu sayede hiper gerçekliğin modelleri, imgeleri ve kodları düşünce ve davranışı kontrol etmeye gelir. Bu postmodern dünyada, bireyler hiper gerçekliğin coşkusu ve bilgisayar, medya ve teknolojik deneyimin yeni evreni için "gerçeğin çölünden" kaçarlar. Gerçeğin çölünden kaçan insanların yarattığı simülasyon evreni Nick Bostrom'un ortaya attığı simülasyon tartışmasında insanlığın zaten içinde yaşadığı bir bilgisayar simülasyon gerçekliği varsayımına dönüşmektedir (2003, s. 248). Medya aracılığı ile yaratılan hiper gerçeklik evreninden bilgisayarların bilinçli zihinler yaratması tartışmalarına gelinen günümüzde Bostrom'a göre teknolojik gelişimimizin şu anki aşamasında, bilgisayarlarda bilinçli zihinler yaratmak için yeterince güçlü bir donanına ya da gerekli yazılıma sahip değiliz. Ancak, teknolojik ilerleme hız kesmeden devam ederse, bu eksikliklerin eninde sonunda üstesinden gelineceği yönünde 
ikna edici argümanlar öne sürülmüştür (Bostrom, 2003, s. 250). Drexler (1985) ve Kurzweil (1999) gibi araştırmacılara göre ise bu aşamanın sadece birkaç on yıl sonra gerçekleşme olasılığ vardır.

İçinde bulunduğumuz 2020'li yıllarda yapay zekâ teknolojilerinin gelişmesi ile birlikte bilgisayarların insanlığı ele geçirerek yöneteceğine dair distopik görüşler ortaya çıkmasına rağmen, henüz böyle bir gerçeklikten söz edilememektedir. Ancak bugün insanlığın vazgeçilmez bir ögesi olan internetin hızla gelişmesi ve yayılması sebebiyle sanal gerçeklik kavramının üzerinde daha çok durulmaya başlanmıștır. Sanal gerçeklik (virtual reality) teknolojisi, başa takılan bir ekran (HMD) ve bir bilgisayara bağlı veri çantası veya veri akışından oluşan sistemlerin geliştirilmesi ve pazarlanmasıyla 1980'lerde ortaya çıkmıştır. Bu teknolojiler bașa takılan stereoskopik görüş sayesinde ortamı üç boyutlu olarak simüle etmişlerdir. Kullanıcılar, vücut parçalarının konumlarını ve hareketlerini izleyen ve bilgisayarın çıktılarını kaydedilen konumlara bağlı olarak değiștirmesine izin veren öğeler olan veri takımı ve veri sayfası aracılığıyla simüle edilmiş ortamlarda gezinebilir ve etkileşime girebilirler. Bu teknoloji sanal gerçeklik ile neyin kastedildiğini tanımlamaya da yardımcı olmuştur. Etkileşimin birden çok duyusal kanal üzerinden gerçekleştiği ve dokunsal ve konumlandırma geri bildirimini içeren sürükleyici, etkileşimli, üç boyutlu, bilgisayar tarafından oluşturulan bir ortamdır. $\mathrm{Bu}$ tür yeni kavramların ve dünyaların ortaya çıkması, gerçeklik ve sanal arasındaki sınırları da bulanıklaştırmıştır.

Bilgisayar çağında, "sanal" kelimesi, bir bilgisayar tarafından simüle edilen, sanal bellek gibi, aslında bir işlemcinin içine yerleștirilmemiş, ancak yine de bu şekilde işlev gören bellek olan şeylere atıfta bulunmaya başlamıştır. Brey’e göre (2008, s. 365-366) "sanal" kelimesinin bilgisayar temelli anlamı, "sanal" ın geleneksel anlamı ile daha çok uyumludur. Pratik olarak gerçek ancak resmi olarak gerçek değildir. Örneğin, sanal bellek, gerçek olmayan bellek değil, gerçek bellek olarak etkin bir şekilde işlev görebilen bir fiziksel bellek simülasyonudur. Simülasyonlar, gerçek dünyadaki varlıkların algısal veya işlevsel benzerlikleri olan sanal versiyonlarıdır, ancak karşılık gelen gerçek dünya eşdeğerinin pragmatik değerine veya etkilerine sahip değillerdir. Brey, bu durumda pek çok sanal varlığın fiziksel emsalleri kadar gerçek olabileceği sonucuna varılabileceğini belirtmektedir. $\mathrm{Bu}$ nedenle de $\mathrm{Bu}$ nedenle sanallık ve gerçeklik birbirine zıt değildir. Bununla birlikte, çoğu fiziksel nesneyi ve süreci içeren sıradan gerçekliğin büyük bir kısmı, sanal biçimde ontolojik olarak yeniden üretilemez.

İnsan olmanın, var olmanın ve gerçekliğin ne olduğu sorularının iç içe geçtiği kavramları içinde barındıran The Congress filmi, bu cevaplanması zor soruların yanına insanın fiziksel yapısına ait güzellik ve gençlik mitlerini de ekleyerek başka bir gerçeklik evreni oluşturan sinemada nasıl işlendiğini sarmal bir yapıda incelemektedir. Gerçekliği animasyon ile birleştiren, distopik bir gerçeklikten kaçmak ve sanal bir gerçeklikte "sonsuza kadar" istedikleri şekillerde yaşamaya gönüllü olmuş insanların dünyalarına ışık tutan film, reel dünyada üretilen sanal düşüncelerin insanların beden ve zihin algıları ile nasıl oynadığının da altı çizmektedir.

\section{The Congress Filminde Gerçeğin ve Animasyonun Bulanık Dünyası}

Yarı gerçek, yarı animasyon şekilde bir Hollywood yıldızının teknolojik gelişmeler ışığında yalnızca simüle edilebilecek "parçalarına" ihtiyaç duyulması ile başlayan bir yolculuğun anlatıldığı film, İsrailli yönetmen Ari Folman tarafından 2013 yılında çekilmiştir. Bir önceki uzun metraj filmi olan Waltz with Bashir (Beşir'le Vals) ile 2009 yılında en iyi 
yabancı film Oscar'ına aday gösterilmiş yönetmen, Stanislaw Lem'in hikâyesini gerçeği kabul etmeye karşı direnişimizi ve bunun sonucunda kaçınma ihtiyacını canlandırmak için filme uyarlamış ve animasyon teknolojilerini distopik aygıtın merkezine yerleștirmiștir. $\mathrm{Bu}$ şekilde, The Futurological Congress öyküsü bilginin manipülasyonu ve özgürlüğün olmaması hakkında bir alegori olmasına rağmen Folman, Lem'in kolektif olarak organize edilmiş rüya fikrini çok yakın bir geleceğe taşıyarak Hollywood'un da içinde olduğu bir hikâyeye dönüştürmüștür.

İki ünlü film şirketinin isminin birleșiminden oluşan Miramount film şirketi reel dünyada var olduğu şekliyle filmde rol alan Robin Wright ile bir anlaşma sonrası yollarını ayırmak istemektedir. Filmin açılışında Miramount beklendiği üzere bir film yapım şirketi iken, filmin sonunda fütüristik bir distopik toplumun arkasındaki baskın güç yapısı haline dönmektedir.

Böyle bir egemenliğe giden yol Miramount başkanı Jeff Green'in (Danny Huston) dünyaya mal olmuş aktörlerini sinemanın geleceğini kabul etmeye ikna etmesiyle başlar. Tüm oyuncuların tamamen dijitalleştiği bir süreç olan tarama sayesinde Miramount, oyuncularını istediği projeye istediği şekilde yerleștirme planları yapmaktadır. Böylelikle gerçek hayattaki aktörleri kullanmanın getirdiği huzursuzluk ve şikâyetten kaçınma niyetindedir. Önümüzdeki yirmi yıl boyunca benzerliğinin ve isminin kullanılmasına izin vermesi için imza atması istenen oyunculardan birisi Robin Wright'tir. Kırk dört yaşında olan Wright, kariyerinin başlarında onu daha popüler hale getirecek rolleri almayı bırakmıștır. Yavaş yavaș sağır olmasına neden olan bir hastalıktan mustarip küçük oğlu Aaron (Kodi Smit-McPhee) ile setlerde çok fazla zaman geçirme arzusunu uzun zaman önce kaybetmiştir. Henüz genç olmasına ve çalışmayı arzulamasına rağmen stüdyonun sonsuza kadar genç, dijital bir versiyonunu yaratma teklifine direnir. Ancak her ne kadar fikir tatsız olsa da hayatına ve oğlunun kötüleșen durumuna bakınca kontratı imzalamayı kabul eder. Bu noktadan sonra film yirmi yıl ileriye atlar ve üç boyutlu (3D) olmaktan çlkarak iki boyutluya (2D) döner.

Stanislaw Lem'in aynı isimli kısa öyküsünden yola çıkılarak çekilen film kırk beşinci dakikadan sonra gerçeklikten koparak halüsinasyonlarla yaratılan animasyonun da işin içine girdiği başka bir evrene taşınır. Bu evrende Wright, stüdyosu tarafından bir Fütürist Kongre'ye davet edilir (kısıtlı, animasyonlu bir bölge) ve Jon Hamm'ın oynadığı kır saçlı bir erkeğin de dâhil olduğu tuhaf bir zihinsel casusluğa karışır. Bu çizgi- animasyon dünyasına girmeden önce Wright, kapıdaki güvenlik görevlisinin içmesini zorunlu kıldığı bir sıvıyı alarak kongrenin yapılacağı binaya doğru ilerler. Filmin ikinci yarısı bambaşka bir evrende bilindik ve önemli tarihi karakterlerin onlarcasının bir arada olduğu bir kaos ve aynı zamanda festival havasında geçer.

Yirmi yıl sonra, 2033'te Robin Wright, Hollywood yapısının tamamen ortadan kaldırılacağının farkında olmadan sözleşmesinin yenilenmesini imzalamak için "kısıtlı animasyon bölgesini", Miramount'un yeni merkezi olan Abrahama Şehrini ziyaret eder. Eski sektörün kalıntıları bunalımlı senaryo yazarları, son teslim tarihlerini karşılamayan animatörler, karakterlerine âşık olan çizerler silinmeli, yerine yeni sistemin sunduğu özgür deneyim ile birlikte kullandıkları kimyasal yardımıyla bir kahramanlık yanılsamasını uyanıkken görülen bir rüya olarak tecrübe edecek karakterlere yer verilmelidir. Bu yeni sistem şunu önermektedir: Tom Cruise olabilecekken neden kendiniz olasınız ki?

The Congress filmi, tamamen animasyon bir film olmasa da Ari Folman, Hollywood hakkındaki görüşünü, kapitalizme yönelik eleştirisini ve her şeyden önce sanalın 
gerçeğe üstün gelebileceği bir gelecek korkusunu ileri sürmek için animasyon fikrini kavramsal bir araç olarak kullanır (Hernandez, 2019, s. 224). Kriger'e göre (2012, s. 6) animasyon, tamamen gözü kandırmak ile ilgilidir, gerçekte amacı gözün aslında neyin olmadığını görmesini sağlamaktır. Bu dünyada hiçbir şey gerçek değildir ancak göze bu dünyanın gerçek olduğunu düşündürürsün. Göz kandırılabilir çünkü o dünyanın kurallarını kabul eder.

The Congress filminde sanatçıların dijitalleşmesi, yalnızca modellerini değil, aynı zamanda tüm üretim sistemini ve dolayısıyla toplum kavramını da yok eden yağmacı bir eylem haline gelmektedir. Filmde, Robin Wright'ın taranma konusundaki temel kaygısı, insan unsurundan çoktan vazgeçmeye karar verdiği için, artık insani olmayan bir sistemin suç ortağı olma duygusudur. Aslında filmde, film yıldızlarının işbirlikçiliği, film yapımının "yapısının sökülmesi" ile sona erecek zincirleme bir reaksiyona ve nihayet çöküşüne yol açar. Bu noktada yönetmen Folman'ın Jean Baudrillard'ın (2003, s. 280) sanal olanın nihayetinde gerçeğin, kültürün ve insani olanın kıyameti haline geleceği düşüncesini paylaştığı söylenebilir.

Jane Batkin Identity in Animation (2017) adlı kitabında ünlü animasyon karakterlerinin nasıl yaratıldığından ve onlara nasıl kimlikler verildiğinden bahsetmektedir. 1920'lerin Caz Çağı'nı özetleyen Betty Boop karakterinin, kadın bedenini sosyal, kültürel ve politik bir mücadele alanı olarak sunan, medyatikleștirilmiş ve inşa edilmiş bir arketip olan dönemin flapper olarak adlandırılan genç kadınlarını yansıttığını belirtmektedir. Betty Boop karakteri aşırı büyük kafası ve az giydirilmiş bedeni ile Mulvey'in (Mulvey, 1975) sinemada erkek bakışının üstünlüğü olarak tanımladığı şeyin göstergesi olan, garip bir şekilde çocuksu bir seks sembolünü temsil eder. Bu animasyon karakterindeki kimlik oluşumu, dönemin toplumsal cinsiyet geleneklerini yansıtan röntgenci bir yaratım eylemidir. Animasyon genellikle beden ve kimlik arasındaki ilişki, cinsiyetin akışkanlığı, benliğin gerçekleşmesi ve bireysel ve kültürel hafıza arasındaki ilişkiyle oynar. Folman, animasyonun üzerinde çok sık durulmayan bu yönünü ele alarak filmini yarı canlı yarı animasyon şeklinde çizerek, reel ve fantastik dünya arasındaki bölünmeyi gerçek sanatçı Robin Wright'in olan ve olması beklenen bölünmüş hayatı üzerinden vermektedir.

\subsection{Güzellik Simülasyonu}

Yirminci yüzyıl sanatının karakteristik özelliklerinden biri, hayatın ve eşyaların ticarileştirildiği çağda gündelik kullanımdaki eşyalara atfedilen önemdir. Eco'ya göre (Eco, 2004, s. 374) tüm nesnelerin mallar düzeyine indirgenmesi ve yalnızca değişim değeriyle düzenlenen bir dünyada kullanım değerinin aşamalı olarak ortadan kalkması, gündelik nesnelerin doğasını kökten değiştirmiştir. Bu tanım çerçevesinde nesne kullanışlı, pratik, nispeten ucuz, standarda sahip ve seri olarak üretilmiş olmalıdır. Bu mallar döngüsü içinde, güzelliğin niteliksel yönlerinin giderek artan sıklıkta niceliksel yönlere kaydığı anlamına gelmektedir. Bir nesnenin popülaritesini belirleyen pratikliktir ve pratiklik ve popülerlik, nesnelerin miktarıyla doğru orantılı olarak artan temel modeldir. Başka bir deyişle, nesneler, güzelliklerini ve önemlerini belirleyen belirli tekil özelliklerle kendilerinde var olan aurayı kaybetmişlerdir. Yeni güzellik yeniden üretilebilir ama aynı zamanda geçici ve dayanıksızdır. Yirminci yüzyılda başlayan ve yirmi birinci yüzyılda insan hayatının ayrılmaz bir yargı parçası haline gelen güzellik anlayışı, avangart sanatçıların elli yılı aşkın süredir mücadele ettiği ticari tüketim nesnelerinden ibaret dünya üzerinden (Eco, 2004, s. 418) ilerlemektedir. 
Robin Wright'in hayat öyküsü, Folman'ın gözler önüne sermeye çalıştığı Hollywood yıldız sisteminin oyuncuları tükenene kadar değerli bir malzeme olarak kullanılmasına örnek teşkil edecek cinstendir. Wright 14 yaşında model, 18 yaşında aktör ve 21 yaşında da film yıldızı olmuştur. Ryan, Basinger ve Pfeiffer'in yanında, her yerde bulunan süper sarışın yıldızlar panteonunda yerini alması beklenmiştir. Ancak Wright bir film yıldızı olmak istememiş aksine rol yapmak, oynamak, sanatçı olmak istemiştir. Verdiği bir röportajda (Brooks, 2014) Wright, perdenin arkasındaki stüdyo patronlarının kendisini Amerika'nın tatlı kızı yapmak istediklerini ancak elbisesini havaya uçuracak birçok filmi geri çevirdiğini belirtmektedir. Wright, kendisini ticari olarak yaşayabilir bir oyuncu olarak gösterecek filmler yapmak yerine, çok az kişinin gördüğü küçük, karanlık, tuhaf filmlerde nadir, karanlık, tuhaf roller üstlenmiştir. Forrest Gump (1994, Robert Zemeckis) filminde canlandırdığı aykırı karakter Jenny ile uzun yıllar anılmıştır. Ancak teklifleri geri çevirdiği için zamanla başrol teklifleri kesilmiştir.

Burada kadın sanatçıların olmak istemedikleri yapımların içinde olmamayı tercih ettiklerinde "zor" olarak algılandıkları, eğlence sektöründe kadınlara nasıl kullanım süresi olan ürünler olarak bakıldığı, ne kadar yetenekli ve çalışkan olduklarının önemli olmadığı hikâyesi de gizlidir. Folman'ın da üzerinde durduğu nokta Hollywood yıldız sisteminin oyuncuları insan olarak değil de meta olarak görmesi ve var oluşlarının yalnızca sisteme katkısı olacak parçalarının kullanılması kadarı ile yeterli olacağıdır. Gerçek hayattaki Robin Wright ile kopyası Robin Wright arasında güzellik ve gençlik üzerinden bir anlatı oluşturulması aynı zamanda bu teklifin yapıldığı sanatçıların insan olarak geldikleri noktayı da gözler önüne sermektedir: Stüdyo patronlarının beğenilecek ve ses getirecek karakterlere ihtiyaçları vardır, gerçek insanlara değil. Bir taraftan Wright'in kopyası gerçek modelin üstlenmek istemediği yükümlülükleri sorgusuz sualsiz üstlenebilecek şekilde yaratılacakken, diğer taraftan modelin kopyası sonsuza kadar genç ve güzel olarak yaşayacak ve modelin gerçek hayattaki ölümüne neden olacaktır. Wright, kopyasının yapılmasını kabul ederek gerçek hayatını sonlandırmış olacaktır.

Ari Folman, The Congress filminin "bir sonraki dünyada hakikat arayışı ve kişinin kendi kişiliği hakkında bir hikâye” olduğunu belirtir (Krammer, 2011). Yönetmen, bir aktrisin hayatını başlangıç noktası olarak alarak kimliğinin dijital imgeyle işaretlenmiş yeni film endüstrisinin hizmetinde nasıl yok olduğunu gözlemlemektedir. Film yıldızları kendi filmlerinden ve basında yankılanan kendileri hakkındaki haberlerden oluşan kolektif bir yapıdır. Kendi benlikleri ve fantezi ürünü oldukları benlik arasında bölünmeler yaşarlar. Ünlü Hollywood yıldızı Grace Kelly kendi benliği ve yıldız kişiliği arasındaki bölünmeyi Hollywood'daki herhangi bir taksi şoförü için kısaca Grace Kelly’e benzeyen biri olduğunu söyleyerek anlatmaya çalışmıştır (Hernandez, 2019, s. 229).

Film yapım şirketinin sahibi Wright'in ancak birkaç senesi kaldığını, artık yaşlanmaya başladı̆̆ı için çekiciliğini kaybettiğini, sektörde istenmeyeceğini, güzellik ve gençlik "kaynağının" tükenmiş olduğu iması ile belirtir. Bu nedenle daha geç olmadan Wright'in sahip olduğu güzellik dondurularak korunmalı, ölümlü bedeni ise her daim genç ve güzel kalacak kopyası Wright'e bakarak mutlu olmaya çalışmalıdır. Güzellik sektörünün 2010'lu yıllarda şiddetini arttırarak kadın gençliği ve güzelliği üzerinde yaptığı vurgu, sosyal medya kullanımı ile perçinlenmiş, photoshop gibi uygulamalarla "mükemmelleştirilen" kadın bedeni, tüm "kusurlarından" arındırılarak izleyicisine, takipçisine sunulmuştur. Belirlenen normlar dâhilinde yalnızca güzel ve çekici kabul edilenin varlığına izin vermek, kadının güzelliğinin geçiciliğinin önüne geçmek ve tüketim nesnesi olarak kullanmaya 
devam etmek amacı ile yaratılan paralel evrende kişinin yıldız kimliği kendi benliğinden ayrılarak kullanılmaya devam edecektir.

Filmde, güzellik ve sahip olunan diğer maddi değerlerin insanlar üzerinde bir ego savaşı yarattığı ve yaratılan paralel animasyon evreninde bunların hiçbirine ihtiyaç kalmayacağı düşüncesi "istediğin kişiye dönüşebilme" vaadi ile desteklenmektedir. Tıpkı sanat eserlerinin biricikliklerinin kaybolması gibi, insanların da biricik ve eşsiz olma özellikleri geride bırakılmalı ve insanlar yığınlar şeklinde sistemin ilahlaştırdığı kişilere benzemelidir. Artık geçerli olan gerçeğin birebir kopyalarıdır. Diğer bir deyişle fiziki dünyada yaratılan güzellik algısı, insanlara sonsuzluğun vaat edilmesi ile fantazmatik bir dünyaya taşınmakta ve Wright'in estetiksiz yüzü, yirmi yıl sonra gittiği animasyon şehrinde yine peşine düşülecek ve bir kez daha kar sağlanacak bir metaya dönüşmektedir. Ancak, gerçek dünyaya oğlunu bulmak için dönen Wright, animasyon evreninde güzellikleri ile övünen insanların sefil halleri ile karşılaşır. Güzellik bir yanılsama, bir simülasyondur.

\section{Sonuç}

Bilimkurgu türünün ilk günlerinden bu yana en çok işlediği konulardan biri olan insanlığın başka bir gezene, başka bir zamana veya evrene yolculuğu genellikle kendi dışında keşfettiği yeni bir türle de perçinlenir. Dünya üzerinde gerçekleşen bir felaketin ardından yaşanacak yeni bir yer arama düșüncesi, günümüzde teknolojinin gelişmesi ve belirli uzaklıklarda olsa da çeşitli gezegenlere gidebilmesi ile geçekleşmeye oldukça yaklaşmıştır. Ancak insanlığın kendinden kaçarak, kendisinin başka bir formunun simülasyon bir evrende yaşaması için gerçek hayatından feragat etmesi başka bir gezegene gitme düşüncesini bambaşka bir boyuta taşımaktadır.

Ari Folman'ın yönettiği The Congress filmi (2013), Polonyalı yazar Stanisław Lem tarafından yazılan bilimkurgu romanı The Futurological Congress'in farklı bir şekilde yeniden okunmasını sağlar. Bu, bir meslek olarak sinemaya, hayal gücüne sığınak olarak animasyona ve ilerleme dediğimiz şeyle temasa geçtiğinde kaçınılmaz olarak değişen insana dair nostaljik bir bakışla renklenen bir yeniden sunumdur. Folman, bir yönetmen olarak sinemanın dijitalleşen dünyada nasıl bir duruma evrilebileceği üzerinden bir okuma yaparken, diğer taraftan oyuncuların da dijitalleşmeye başladığı bu platformda nasıl algılanacakları üzerinde durmaktadır.

Güzellik mitini, Hollywood yıldız sistemi ile birleştiren film, simülasyon kavramının da eklendiği bir yapı içerisinde sanatın konusu olan insanın sanal olarak yaratılan bu evrende neye evrildiğini sorgulamaktadır. Bu sorudan yola çıkılarak belirtilen yapılanmanın çözümlenebilmesi için çalışma güzellik miti, Hollywood yıldız sistemi ve simülasyon kavramlarının tanımları yapılarak bölümlere ayrılmış ve ortaklaştıkları noktalar film üzerinden aktarılmıștır.

Bugün sosyal medya kullanımının günlük hayatın büyük bir bölümünü kaplaması ve güzelliğin karlı bir tüketim nesnesine dönüşmesi, bu kavramın gerçeklik sınırları dışarısına taşarak insanlarda yanlış algı oluşturmasına neden olduğu söylenebilmektedir. Filmde, sinema sektörünün ve yapım şirketlerinin yıldız oyunculara yaklaşımlarının eleștirisi birer metaya dönüştürülmeleri üzerinden yapılmaktadır. Sanatçıların dijitalleşmesinin, yalnızca modellerini değil, aynı zamanda tüm üretim sistemini ve dolayısıyla toplum kavramını da yok eden yağmacı bir eylem haline geldiği görülmektedir. Genç, güzel, yıldız olma ve yașlanan beden algısı, simülasyon evreni, film yapım şirketlerinin yaklaşımı 
gibi kodların yönetmenin seyircinin algısını sorgulaması üzerinden vermesi, yapılan içerik analizi yöntemi yardımı ile açımlanmıștır. Çalışmada üzerinde durulan nokta, gerçek ve simülasyon kavramlarının iki farklı evrendeki sunumunun reel bir Hollywood yıldızının bölünen hayatı, yalnızca geçici güzelliğine verilen meta değeri ve kişilik bölünmesi üzerinden veren The Congress (2013) filminde, simülasyon kavramının kitle iletişim araçları alanından çıkarak içinde yaşamayı tercih ettiğimiz simülasyon evrenine dönüşmesi durumudur. Simülasyon kavramı, bireylerin modern toplumdaki yaşamlarının üzerinde kontrol sahibi olmadıkları kurumlara, yapılara ve koşullara büyük ölçüde bağımlı hale gelmesi ve bireylerin özerk olmalarının giderek imkânsızlaşması üzerinden Baudrillard'ın metalaştırma, makineleşme ve pazar ilişkileri yaklaşımı çerçevesinde verilmiştir. Güzellik miti de günümüzde kişisel fiziksel imajın, sosyal çevrede ayrı bir yer edinmenin bir yolu olması ve bu statüyü elde etmek için vücut görünümüne yapılan yatırımların kadınlar ve erkekler için artan önemi üzerinden incelenmiş ve iki kavramı birleştiren pazarın sinematik evrende nasıl yansıtıldığı üzerinden bir çözümleme yapılmıştır.

Güzellik algısının yanılsama ve gerçeklik teorileri ile harmanlanarak sunulduğu filmde bu algının simülasyon evreninde nasıl yansıtıldığı sorunsalından yola çıkılan çalışmada şu sonuca varılmıştır: Yönetmen Folman, bir rüya fabrikası olan sinemanın izleyicisine vadettiği renkli dünyanın ardında yatan endüstriyi ve bu endüstriyi besleyen güzellik mitini gerçek bir Hollywood yıldızının hayatı üzerinden göstererek, gerçekmiş gibi görünen ve bu uğurda tüm öz benliklerinden feragat edebilecek insanların bir simülasyonun peşinde sürüklendiklerinin altını çizmeye çalışmıştır.

\section{Kaynakça}

Alperstein, N. (1991). Imaginary relationships with celebrities appearing in television commercials. Journal of Broadcasting\&Electronic Media, 43-58.

Bacon, F. (1884). The works of Francis Bacon. New York.

Banes, M. (1912). The mad search for beauty: And the slight chance that the average actress can guide the average woman. The Green Book Magazine, s. 953.

Banner, W. (1983). American beauty: A social history through two centuries of the American idea, ideal, and image of the beautiful woman. Figueroa Press.

Batkin, J. (2017). Identity in Animation: A journey into self, difference, culture and body. Routledge.

Baudrillard, J. (1967). Review of understanding media. L'Homme et la Societe Nr. 5, 227.

Baudrillard, J. (2003). Requiem for the media. N. Wardrip-Fruin içinde, The New Media Reader (s. 277-288). Cambridge: The MIT Press.

Baudrillard, J. (2014). Simülarklar ve simülasyon. Doğu Batı Yayınları.

Bostrom, N. (2003). Are you living in a computer simulation? Philosophical Quarterly Vol. 53 No.211, 245-255.

Brey, P. (2008). Virtual reality and computer simulation. K. Himma içinde, The handbook of information and computer ethics (s. 361-384). Wiley.

Brooks, X. (2014). Robin Wright: I am in my 40s and I don't inject my face with Botox. The Guardian: https://www.theguardian.com/film/2014/aug/07/robin-wright-arifolman-the-congress adresinden alındı 
Campbell, K. (1948). Hollywood, more than ever, going for those ad tieups. Variety.

Children, T. M. (2015, January 21). Past Research Reports. January 16, 2021 tarihinde https://www.commonsensemedia.org/research/past-research-reports\# adresinden alındı

DeCordova, R. (1990). Picture personalities: The emergence of the star system in America. Urbana: University of Illinois Press.

Drexler, K. (1985). Engines of creation: The coming era of nanotechnology. London: Fort Estate.

Eco, U. (2004). On beauty: A history of western idea. Seeker\&Warburg Publishing.

Frith, K. (2014). Globalizing beauty: A cultural history of the beauty industry. Conference: Journal of Communication, (s. 1-33). Seattle.

Hüttner, S. (2010). Dirty sexy money": Commodified identities and acts of consumption in Christopher Shinn's "other people and where we come from. South Atlantic Review Vol. 75 No. 3, 25-40.

Harrison, K. (2006). The relationship between media consumption and eating disorders. Journal of Communication Vol 47 (1), 40-67.

Hermannsdottir, M. (2011). Self-Identity in modernity. Yayınlanmamış Yüksek Lisans Tezi. University of Akurevi, Faculty of Social Sciences.

Hernandez, L. (2019). Animation in the core of dystopia: Ari Folman's the Congress. Animation, 222-234.

Jones, G. (2005). Multinationals and global capitalism. Oxford Publishing.

Kriger, J. (2012). Animated realism: A behind-the-scenes look at the animated documentary genre. Oxford: Focal Press.

Kunzle, D. (2004). Fashion and fetishism: Corsets, tight-lacing and other forms of body sculpture. The History Press.

Kurzweil, R. (1999). The age of spiritual machines: When computers exceed human. New York: Viking Press.

Lem, S. (1971). The futurological congress. Seabury Press.

McClendon, X. (2018, May). The body, fashion and physique. www.exhibitions.fitnyc.edu/ the-body adresinden alınd

McClintock, A. (1995). Imperial leather: Race, gender and sexuality in the colonial context. New York.

Merriam-Webster. (2021). Merriam-Webster Dictionary. https://www.merriam-webster. com/ adresinden alındı

Miskell, P. (2004). Cavity protection or cosmetic perfection? Innovation and marketing of toothpaste brands in the United States and Western Europe. Business History Review, 29-60.

Moe, B. (1999). Understanding negative body image. New York: Rosen Publishing.

Mulvey, L. (1975). Visual pressure and narrative cinema. Screen Vol. 16 (3), 6-18. 
Routray, S. (2019). Concept of identity in real and virtual world. THL Journal Vol. 4 (5), 133-138.

Saddik, A. (2007). Contemporary American drama. Edinburgh: Edinburgh Press.

Schweitzer, W. (2005). The mad search for beauty: Actresses' testimonials, the cosmetics industry and the democratization of beauty. The Journal of the Gilded Age and Progressive Era, 155-292.

Silverstein, B. (1986). The role of mass media in promoting a thin standard of bodily attractiveness for women. Sex Roles, 519-532.

Skeat, W. (2015). An etymological dictionary of the English language 1884. Generic Publishing.

Swami, V. (2007). The missing arm of venus de Milo: Reflections on the science of physical attractiveness. Book Guild Publishing.

Tiggemann, M. (2011). Sociocultural perspectives on human appearance and body image. T. Cash içinde, Body Image (s. 12-19). New York: The Guilford Press.

White, M. (2009). Graduate Thesis. Representations of the true woman and the new woman in Harper's Bazar. The Iowa State University.

Wolf, N. (1991). The beauty myth: How images of beauty are used against women. Chatto\& Windus Publishing. 


\title{
The Simulation Argument and the Essence of Human Being: The Cinematic Universe of the Perception of Beauty in The Congress
}

\author{
Selen Gökçem Akyıldız (Asst. Prof. Dr.)
}

\section{Extended Abstract}

The perception of beauty, which started to take shape especially on the female body in visual arts, turned into a beauty myth over time, and with the spread of mass media, it reached advertisements, from there to the creation of the beautiful star actress image by infiltrating Hollywood. In the following years, the widespread usage of make-up and then aesthetic operations with the technological developments, and today, the emergence of the perception of beauty in which everyone has perfect dimensions by removing the defects with various programs underlines that the beauty simulation creates a discussion area that should be focused on.

Jean Baudrillard's (2014) asserting that information technology, media and cybernetics have entered an age of simulation where models, signs and codes are mediating the perception of reality and that it is not possible to make a logical distinction between simulation and reality combines with the beauty simulation in Ari Folman's film The Congress (2013), taking the discussion to another dimension. Based on the science fiction story of Stanslaw Lem's The Futurological Congress, the director gave the concept of simulation over the divided life of a Hollywood star, and the animation created with hallucinations by preventing both the intertwined blur of real and fantasy life and the perception of beauty in people is also involved to another universe.

It is possible to say that together with the rising of beauty industry the concept of simulation's scope which was put forward by Jean Baudrillard has been widened. Economy, politics, social life and culture are all governed by the simulation mode; here codes and models determine how goods are consumed and used, how politics emerge, culture is produced and consumed, and daily life is lived. Beauty myth and its presentation through Hollywood stars created another simulation universe that big majority of people are ready to give up their core of being human to have another reality. In this sense, The Congress (Ari Folman, 2013), which contains concepts in which the questions of being human, being and what is reality are intertwined, by adding the myths of beauty and youth belonging to the physical structure of human beings to these hard-to-answer questions, it examines in a spiral structure how they are processed in cinema, which creates another universe of reality. The film, which combines reality with animation, sheds light on the worlds of people who volunteered to escape from a dystopic reality and live in a virtual reality "forever" the way they want, also underlines how virtual thoughts produced in the real world play with people's perceptions of body and mind.

The point focused on in this study is that in The Congress (2013), where the presentation of the concepts of real and simulation in two different universes, the dividing life of a real Hollywood star is based on the commodity value given only to its temporary beauty and the division of personality, the concept of simulation is the case of the transformation of the concept of simulation into the simulation universe we prefer to live in. While the first part of the study focuses on beauty perception, beauty myth and simulation concepts, 
in the second part, The Congress (2013) movie is analyzed by discussing the concepts of beauty and simulation mentioned in the first part based on content analysis.

The fact that film production companies approach actors as commodities, cooperate as long as their viewership is high, and only need their name when they lose their physical appeal is given through Robin Wright, a true Hollywood star. In film, the digitalization of the artists becomes a predatory act that destroys not only their models, but also the entire production system and hence the concept of society. The simulation animation universe, which can be reached by using a chemical drink, is a place where people become uniform, their autonomy is lost, and their selves turn into various iconic figures for a short time. This place is where reality and fantasy blur is where the meanings people attribute to the realities of the world become blurred and emptied. As conclusion, it can be said that the director Folman, by showing the industry behind the colorful world and the myth of beauty that feeds this industry through the life of a real Hollywood star, cinema, which is a dream factory, tries to underline the fact that people who seem to be real and who can give up all their selves for this cause are dragged in the pursuit of a simulation.

Keywords: Cinema, Simulation theory, Beauty myth, Animation, Reality.

Bu makale intihal tespit yazııımlarıyla taranmıştır. Intihal tespit edilmemiştir.

This article has been scanned by plagiarism detection softwares. No plagiarism detected.

Bu çalışmada "Yükseköğretim Kurumları Bilimsel Araştırma ve Yayın Etiği Yönergesi” kapsamında uyulması belirtilen kurallara uyulmuştur.

In this study, the rules stated in the "Higher Education Institutions Scientific Research and Publication Ethics Directive" were followed.

Yazarların çalışmadaki katkı oranları eşittir.

The authors' contribution rates in the study are equal.

Çalışma kapsamında herhangi bir kurum veya kişi ile çıkar çatışması bulunmamaktadır.

There is no conflict of interest with any institution or person within the scope of the study. 